\title{
Effect of high energy intake on carcass composition and hypothalamic gene expression in Bos indicus heifers
}

\author{
Juliane Diniz-Magalhães', Lígia Garcia Mesquita', Marina Vieira de Carvalho', Anna Beatriz \\ Escarpellin Machado', José Rodrigo Valim Pimentel ${ }^{2}$, Luis Felipe Prada e Silva ${ }^{1^{*}}$

\footnotetext{
${ }^{1}$ Universidade de São Paulo, Faculdade de Medicina Veterinária e Zootecnia, Departamento de Nutrição e Produção Animal, Pirassununga, SP, Brazil.

2 Universidade de São Paulo, Faculdade de Medicina Veterinária e Zootecnia, Departamento de Reprodução Animal, Pirassununga, SP, Brazil.
}

\begin{abstract}
The objective of this study was to evaluate the effect of high or low energy intake on carcass composition and expression of hypothalamic genes related to the onset of puberty. Twenty-four prepubertal Nellore heifers, 18-20months-old, with $275.3 \pm 18.0 \mathrm{~kg}$ body weight (BW), and 4.9 \pm 0.2 (1-9 scale) body condition score (BCS) were randomly assigned to two treatments: high-energy diet (HE) and low-energy diet (LE). Heifers were housed in two collective pens and fed diets formulated to promote average daily gain of 0.4 (LE) or $1.2 \mathrm{~kg}$ (HE) BW/day. Eight heifers from each treatment were slaughtered after the first corpus luteum detection - considered as age of puberty. The 9-10-11th rib section was taken and prepared for carcass composition analyses. Samples from hypothalamus were collected, frozen in liquid nitrogen, and stored at $-80{ }^{\circ} \mathrm{C}$. Specific primers for targets (NPY, NPY1R, NPY4R, SOCS3, OXT, ARRB1, and IGFPB2) and control (RPL19 and RN18S1) genes were designed for real-time PCR and then the relative quantification of target gene expression was performed. High-energy diets increased body condition score, cold carcass weight, and Longissimus lumborum muscle area and decreased age at slaughter. High-energy diets decreased the expression of NPY1R and ARRB1 at 4.4-fold and 1.5-fold, respectively. In conclusion, the hastening of puberty with high energy intake is related with greater body fatness and lesser hypothalamic expression of NPY1 receptor and of $\beta$-arrestin1, suggesting a less sensitive hypothalamus to the negative effects of NPY signaling.
\end{abstract}

Key Words: cattle, energy supplementation, neuropeptides, puberty, reproduction

\section{Introduction}

The onset of puberty is characterized by the first ovulation, preceded by a gradual increase in luteinizing hormone (LH) pulse frequency, inducing ovulation of a dominant follicle (Rawlings at al., 2003). Nutrition is a key factor determining the initiation of reproduction in cattle and other mammals and body weight gain and adiposity play important roles in the commencement of puberty (Velazquez et al., 2008; Amstalden et al., 2014).

There is a clear effect of diet and energy intake on hastening of puberty in heifers and changes in the diet can

Received: June 7, 2016

Accepted: June 8, 2017

*Corresponding author: I.pradaesilva@uq.edu.au http://dx.doi.org/10.1590/S1806-92902017000800006

How to cite: Diniz-Magalhães, J.; Mesquita, L. G.; Carvalho, M. V.; Machado, A. B. E.; Pimentel, J. R. V. and Silva, L. F. P. 2017. Effect of high energy intake on carcass composition and hypothalamic gene expression in Bos indicus heifers. Revista Brasileira de Zootecnia 46(8):664-669.

Copyright (C) 2017 Sociedade Brasileira de Zootecnia. This is an Open Access article distributed under the terms of the Creative Commons Attribution License (http://creativecommons.org/licenses/by/4.0/), which permits unrestricted use, distribution, and reproduction in any medium, provided the original work is properly cited. also lead to changes in carcass composition by the time of puberty (Lohakare et al., 2012). Day et al. (1986) reported that restriction of dietary energy intake prevents the prepubertal rise in secretion of $\mathrm{LH}$ and delays the initiation of puberty. However, the hypothalamic mechanism by which diet modulates puberty is not fully elucidated (Foster and Hileman, 2015).

At the hypothalamic level, changes in energy intake can alter secretion of neuropeptide Y (NPY), which acts as an inhibitor of gonadotropin-releasing hormone $(\mathrm{GnRH})$. Intra-cerebro-ventricular administrations of NPY in goats demonstrated that NPY acts on LH secretion through inhibition of GnRH pulses (Roland and Moenter, 2011). Besides alteration on NPY, acute and chronic changes on the animal energetic status can alter expression of other genes in the hypothalamus-pituitary-gonadal axis (Allen et al., 2012). The identification of the key mediators signaling the nutritional status of the animal to the hypothalamus at the time of puberty is important for the development of nutritional, pharmacological, and breeding strategies aiming to reduce the age of first calving in the Brazilian herd.

The objective of this study was to evaluate the effect of high or low energy intake on carcass composition at 
puberty and expression of NPY and other hypothalamic genes related to sexual maturation of $B$. indicus heifers.

\section{Material and Methods}

All experimental procedures are in agreement with the Guide for Care and Use of Agricultural Animals in Agricultural Research and Teaching (Vaughn, 2012) and research on animals was conducted according to the institutional committee on animal use (protocol number 1331/2008).

The experiment was conducted in Pirassununga, state of São Paulo, southeast of Brazil (21 $599^{\prime} 46^{\prime \prime} \mathrm{S}$, $47^{\circ} 25^{\prime} 33^{\prime \prime} \mathrm{W}, 627 \mathrm{~m}$ above sea level) from June 2008 to January 2009. According to the Köppen system, the climate in Pirassununga is Cwa type, characterized by hot and wet summer (mean temperature of the hottest month higher than $22^{\circ} \mathrm{C}$ ), dry winter (mean temperatures of the coldest month below to $18{ }^{\circ} \mathrm{C}$ ), and $\sim 1100 \mathrm{~mm}$ of annual rainfall. The rainy season lasts from October to March and the dry season from April to September.

Twenty-four prepubertal heifers (12 per treatment) were used in this experiment. The heifers were 18 to 20 months old, with $275 \pm 18 \mathrm{~kg}$ body weight (BW) and $5 \pm 0.2$ body condition score (BCS) (scale of 1 to 9). Animals were randomly assigned to each of two treatments: high-energy diet (HE) or low-energy diet (LE). Diets were formulated to promote weight gains of $0.4 \mathrm{~kg} /$ day (LE) or $1.2 \mathrm{~kg}$ /day (HE). Heifers were fed ad libitum once a day and were weighted and had their BCS evaluated twice weekly. Diets were formulated according to NRC (2000) to promote an average daily gain (ADG) of $0.4 \mathrm{~kg} / \mathrm{d}$ (LE) or $1.2 \mathrm{~kg} / \mathrm{d}(\mathrm{HE})$ and both diets were offered at ad libitum intake (Table 1).

Age at puberty was defined as the age of first detection of a corpus luteum (CL) by transrectal ultrasonography conducted twice weekly and confirmed by serum progesterone above $1 \mathrm{ng} / \mathrm{mL}$. Eight heifers from each treatment were slaughtered on the second day after the first CL detection in an experimental abattoir. To avoid damaging the hypothalamus, captive bolt stunning was used to render animals insensible with a single shot on the spinal cord. According to Grandin (2005), a satisfactory stunning score is considered to be around 95\% for animal welfare. In the present study, the stunning score was $97.2 \%$. After stunning, the jugular vein was severed clean to allow bleeding, the head was removed, and the brain collected.

Samples from the hypothalamus were collected, frozen in liquid nitrogen, and stored at $-80{ }^{\circ} \mathrm{C}$ for subsequent RNA extraction. To locate the hypothalamus, structures from diencephalon were used as delimiters: dorsally to the median eminence, caudally to optic chiasm, frontally to mammillary body, and ventrally to third ventricle (Klein, 2012).

All half-carcasses were stored in a cold chamber at 0 to $2{ }^{\circ} \mathrm{C}$ for $24 \mathrm{~h}$, after which the cold carcass weight was obtained. The Longissimus lumborum muscle area (LMA) and subcutaneous fat thickness were measured at the 12 th rib on the right hemi-carcasses. To estimate carcass chemical composition, the 9-10-11th rib section (HH section) was removed from the left half-carcasses, according to procedures outlined by Cônsolo et al. (2015), and stored at $-20{ }^{\circ} \mathrm{C}$.

The HH sections were cut by a band saw, ground two times to pass through a $23-\mathrm{mm}$ sieve, and two times at an 8-mm sieve. Samples were homogenized and about $350 \mathrm{~g}$ were stored in four petri dishes. Samples were lyophilized to constant weight to determine the water content and the chemical composition of the $\mathrm{HH}$ section was estimated using equations developed for growing Nellore cattle (Lanna et al., 1995).

The water content of the $\mathrm{HH}$ section was used to estimate empty body weight (EBW) composition using equations developed for Nellore cattle (Putrino et al., 2006). After calculation of EBW composition, data were used to calculate composition (crude protein and ether extract) of EBW gain. The protein and ash contents on EBW were obtained using the protein:water and ash:water ratios of 0.3009 and 0.0747 , respectively (Lanna et al., 1999).

Hypothalamus samples were subjected to total RNA extraction using TRIzol (Life Technologies, Brazil)

Table 1 - Ingredient composition and analysis of the high- and low-energy diets

\begin{tabular}{|c|c|c|}
\hline & \multicolumn{2}{|c|}{ Diet } \\
\hline & High energy & Low energy \\
\hline \multicolumn{3}{|l|}{ Diet composition ( $\mathrm{g} \mathrm{kg}^{-1}$ of DM) } \\
\hline Corn silage & 401 & 554 \\
\hline Sugarcane bagasse & - & 312 \\
\hline Ground corn & 401 & - \\
\hline Soybean meal & 182 & 116 \\
\hline Urea & - & 1.0 \\
\hline Minerals and vitamins & 1.5 & 0.8 \\
\hline \multicolumn{3}{|l|}{ Ration analysis (DM basis) } \\
\hline aNDF $\left(\mathrm{g} \mathrm{kg}^{-1} \mathrm{DM}\right)$ & 307 & 571 \\
\hline Total digestible nutrients ${ }^{1}\left(\mathrm{~g} \mathrm{~kg}^{-1}\right)$ & 751 & 595 \\
\hline Gross energy $^{2}\left(\mathrm{Mcal} \mathrm{kg}^{-1}\right)$ & 43 & 42 \\
\hline Metabolizable energy $($ Mcal kg-1) & 27 & 22 \\
\hline Crude protein $\left(\mathrm{g} \mathrm{kg}^{-1}\right)$ & 156 & 126 \\
\hline Ether extract $\left(\mathrm{g} \mathrm{kg}^{-1}\right)$ & 36 & 23 \\
\hline $\operatorname{Lignin}\left(\mathrm{g} \mathrm{kg}^{-1}\right)$ & 16 & 47 \\
\hline Ash $\left(\mathrm{g} \mathrm{kg}^{-1}\right)$ & 56 & 68 \\
\hline
\end{tabular}

DM - dry matter; aNDF - ash-free neutral detergent fiber.

${ }^{1}$ Estimated with NRC (2001) equations.

${ }^{2}$ Obtained in bomb calorimeter. 
reagent protocol following the manufacturer's instructions. Quality of RNA extraction was determined with 1.2\% $(\mathrm{w} / \mathrm{v})$ agarose-formaldehyde gel electrophoresis to verify the integrity of the $5.8 \mathrm{~S}, 18 \mathrm{~S}$, and $28 \mathrm{~S}$ rRNA bands and by measuring the absorbance at 260 and $280 \mathrm{~nm}$ using GeneQuant Pro (Amersham Biosciences). To avoid genomic contamination, $1.5 \mu \mathrm{g}$ of total RNA was treated with DNase I (Life Technologies, Brazil) before proceeding to cDNA synthesis using the Superscript II cDNA synthesis kit (Life Technologies, Brazil).

Specific primers for the target genes - arrestin, $\beta 1$ (ARRB1), insulin-like growth factor binding protein 2 (IGFBP2), NPY, NPY receptors (NPY1R and NPY4R), oxytocin (OXT), suppressor of cytokine signaling 3 (SOCS3) - and for the constitutive reference genes ribosomal protein L19 (RPL19) and 18S ribosomal RNA (RN18S1) - were designed for real-time PCR (qPCR) using Primer Express 3.0 software (Life Technologies) (Table 2), based on bovine sequences deposited on GenBank.

Relative gene expression quantification of ARRB1, IGFBP2, NPY, NPY1R, NPY4R, OXT, and SOCS3 was performed using RPL19 or RN18S1 to normalize the reactions. The real-time PCR reactions were performed using cDNA hypothalamic samples, $10 \mu \mathrm{L}$ of SYBR Green master mix $2 \mathrm{X}$ (Life Technologies, Brazil), $0.25 \mathrm{mM}$ of each primer, and water up to a final volume of $20 \mu \mathrm{L}$. Thermal cycling parameters were as follows: an initial denaturing step of $94{ }^{\circ} \mathrm{C}$ for $10 \mathrm{~min}$, followed by 44 cycles of denaturing $\left(94^{\circ} \mathrm{C}\right.$ for $\left.15 \mathrm{~s}\right)$, annealing/elongation $\left(60^{\circ} \mathrm{C}\right.$ for
$1 \mathrm{~min})$, a melting curve program $\left(60-95{ }^{\circ} \mathrm{C}\right.$ with a heating rate of $0.3{ }^{\circ} \mathrm{C}$ per cycle), and a final cooling cycle of $4{ }^{\circ} \mathrm{C}$. All reactions were performed in triplicate wells.

Amplification efficiency of all genes was verified by a dilution curve with a series of cDNA concentrations and quantification was performed only when efficiency was not different than $100 \%$ (Yuan, 2006). All analyses were done based on second derivative maximum method. The StepOne $^{\circledR}$ Detection System (Life Technologies, Brazil) was used to perform the reactions.

All statistical analyses were conducted using SAS (Statistical Analysis System, version 9.1.2). Data were analyzed as a completely randomized design using the MIXED procedure of SAS, according to the following model:

$$
Y_{i j}=\mu+\tau_{i}+e_{i j}
$$

in which $Y_{i j}$ is the observed response, $\mu$ is an overall mean, $\tau_{i}$ is the treatment effect ( $\mathrm{i}=1$ to 2 ), and $e_{i j}$ is the experimental error.

Data on BCS and on carcass composition were considered non-normal and analyzed using the PROC GLIMMIX procedure of SAS. In all comparisons, significance was declared at $\mathrm{P} \leq 0.050$ and tendencies at $\mathrm{P} \leq 0.100$.

\section{Results}

The age at slaughter reflects the time when the first CL was observed and the heifers were considered

Table 2 - Oligonucleotide primer pairs designed for use in real-time polymerase chain reaction (PCR) amplification

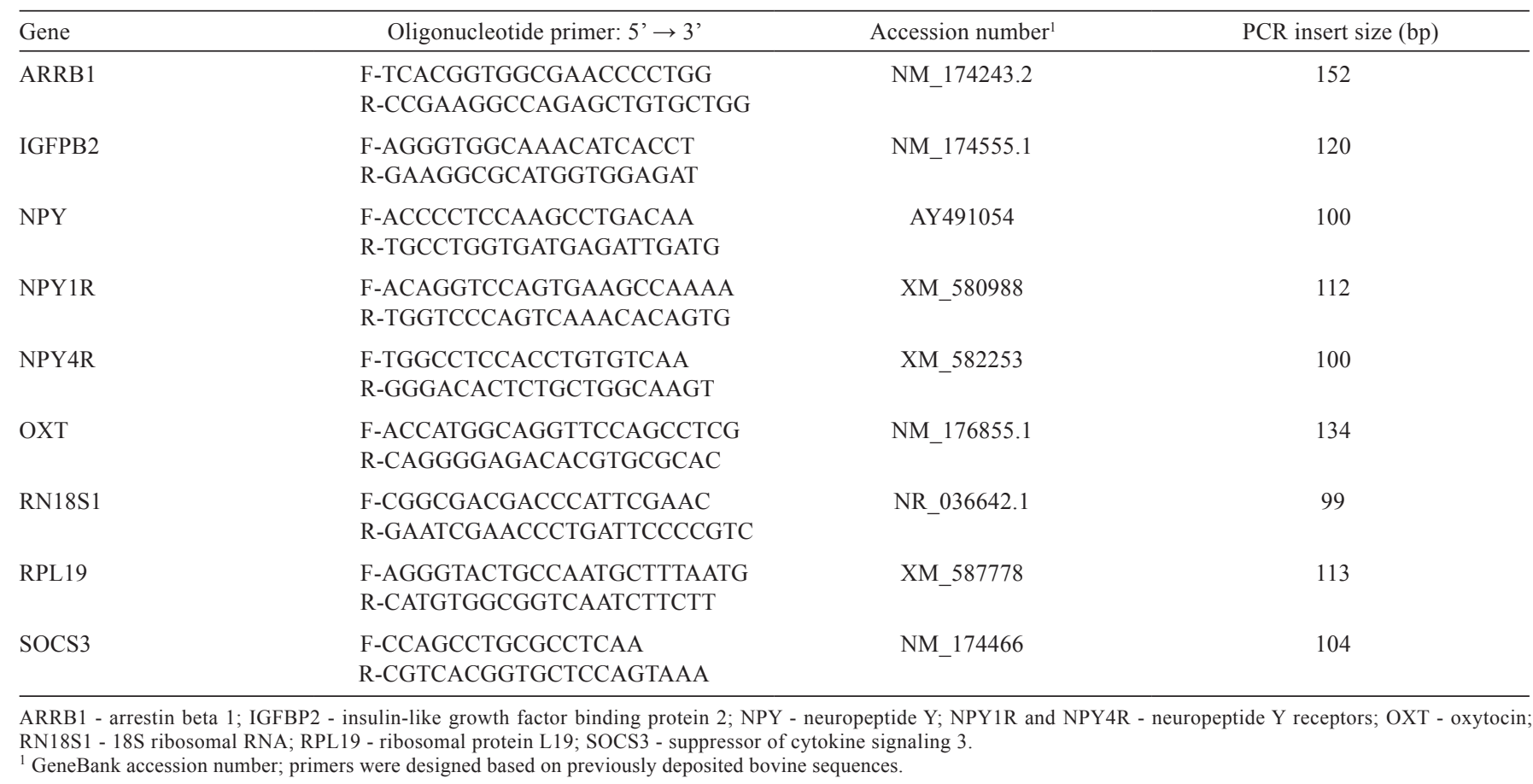


pubertal. Heifers fed the high-energy diet obtained puberty 1.5 months earlier than heifers fed the low-energy diet $(\mathrm{P}<0.010)$ (Table 3). Increasing the energy content of the diet not only anticipated puberty, but also changed BW and body composition at the time of puberty. Feeding heifers a high-energy diet tended $(\mathrm{P}=0.091)$ to increase $\mathrm{BW}$ at puberty and did increase cold carcass weight $(\mathrm{P}=0.022)$ (Table 2). High-energy-fed heifers also had greater BCS at puberty $(\mathrm{P}=0.013)$, but had no difference in backfat thickness $(P=0.234$, Table 2$)$. Regarding the carcass parameters, high-energy diet increased LMA $(\mathrm{P}<0.010)$ but had no effect on carcass chemical composition $(\mathrm{P}=0.440)$.

Our hypothesis was that high-energy diet would hasten puberty and change gene expression of NPY or of its receptors, as well as alter expression of other related genes at the hypothalamus. Energy content of the diet affected NPY1R and ARRB1 expression in the hypothalamus, without altering expression of the other evaluated genes. Heifers fed high-energy diets had reduced expression of NPY1R $(P=0.042)$ and ARRB1 $(P=0.021)$ by 4.4 -fold and 1.5 -fold, respectively (Figure 1). There was no effect of diet on the expression of NPY $(\mathrm{P}=0.753)$, NPY4R $(\mathrm{P}=0.920)$, SOCS3 $(\mathrm{P}=0.242)$, IGFBP-2 $(\mathrm{P}=0.754)$, or OXT $(\mathrm{P}=0.923)$ (Figure 1).

\section{Discussion}

The objective of this study was to verify whether feeding prepubertal heifers a high-energy diet would alter the body composition at puberty and identify hypothalamic molecular pathway by which a high-energy diet could hasten puberty. Limitation of energy during heifer growth is a common event for B. indicus cattle reared in range condition, especially during the dry season, and is a key

Table 3 - Effect of diets on age, live body weight, body condition score, and carcass composition of pubertal Nellore heifers

\begin{tabular}{|c|c|c|c|c|}
\hline \multirow{2}{*}{ Variable } & \multicolumn{2}{|c|}{ Treatment } & \multirow{2}{*}{ SEM } & \multirow{2}{*}{ P-value } \\
\hline & $\mathrm{LE}$ & $\mathrm{HE}$ & & \\
\hline Age at slaughter (months) & 25.5 & 23.1 & 0.7 & $<0.010$ \\
\hline Live body weight at slaughter $(\mathrm{kg})$ & 345 & 366 & 14 & 0.091 \\
\hline Body condition score at slaughter & 4.9 & 5.8 & 0.3 & 0.013 \\
\hline Cold carcass weight (kg) & 174 & 196 & 9.0 & 0.022 \\
\hline Longissimus lumborum area $\left(\mathrm{cm}^{2}\right)$ & 52.5 & 58.2 & 1.8 & $<0.010$ \\
\hline Fat thickness (mm) & 3.4 & 4.4 & 0.8 & 0.234 \\
\hline Empty body weight composition & \multicolumn{4}{|c|}{---g kg-1 of empty body weight--- } \\
\hline Water & 571 & 561 & 13 & 0.440 \\
\hline Dry matter & 500 & 515 & 19 & 0.440 \\
\hline Fat & 211 & 224 & 16 & 0.440 \\
\hline Protein & 172 & 169 & 4 & 0.440 \\
\hline Ash & 42.6 & 41.9 & 1.0 & 0.440 \\
\hline
\end{tabular}

LE - low-energy diet; HE - high-energy diet; SEM - standard error of the mean. factor determining the age of puberty. Samadi et al. (2014) demonstrated that heifers under dietary energy restriction attained puberty later than heifers fed high-energy diets.

The onset of puberty can be defined as the first ovulatory estrus followed by a luteal phase of normal duration (Atkins et al., 2013). In the present study, the onset of puberty corresponds to the slaughter age and heifers fed a highenergy diet were considered pubertal 45 days earlier than heifers fed a low-energy diet. Similar results were found by Nepomuceno et al. (2017), in which grain supplementation of Nellore heifers after weaning increased the percentage of pubertal heifers at 18 months of age.

Changes in the nutritional program during the rearing phase can alter body composition at puberty. Some authors observed that females became pubertal with a greater weight and BCS when subjected to a high-energy diet (Pattherson et al., 1990; Hopper et al., 1993; Yelich et al., 1995). In the present study, LMA was increased by high energy intake as was the cold carcass weight. The increase in LMA was observed in heifers (Zieba et al., 2008) and steers (Amstalden et al., 2000) fed high-energy diets associated with greater amounts of fat. Also, in the present study, heifers fed a high-energy diet had greater BCS at puberty. Therefore, our results support the hypothesis that puberty is not always attained at a definite BW and body composition. Heifers reared with a high-energy diet had heavier carcass and greater LMA and BCS at puberty. The nutrition plan should consider the changes in body composition and the advantages in reducing the age at puberty of replacement heifers.

Contrary to the observed increase in BCS in highenergy-fed heifers, there was no effect of treatment on the carcass chemical composition estimated by the HH section. Visual evaluation of BCS reflects changes in subcutaneous

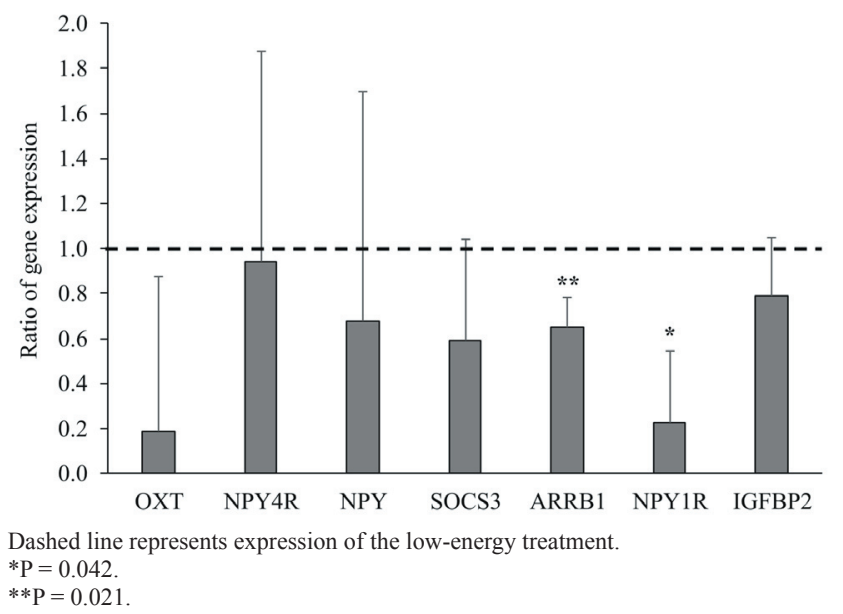

Figure 1 - Hypothalamic relative gene expression of NPY, NPY1R, NPY4R, ARRB1, SOCS3, IGFBP2 and OXT genes on the onset of puberty in Nellore heifers. 
fat especially in the rump area, which was not detected by the chemical composition of the HH section.

The molecular mechanism regulating the onset of puberty seems to be influenced by adipose tissue accumulation. Because BCS, which reflects the subcutaneous adipose tissue, was higher in heifers fed high-energy diets, but there was no difference in the fat percentage of $\mathrm{HH}$ sections, it is possible that different adipose tissue depots have different roles in influencing puberty. The adipose tissue synthetizes leptin, a protein that plays an important role in the sexual maturation process acting as a signal of the energy status to the central reproductive axis (Zieba et al., 2008; Bohler et al., 2010). The role of leptin as the mediator of nutrition and reproduction can be observed in fasting and refeeding experiments. Short-time fasting induces a decrease in $O b$ gene expression (leptin gene) and circulating leptin of prepubertal heifers (Amstalden et al., 2000). At the same time, diminished frequency of LH pulses is observed by short-time fasting (Amstalden et al., 2000). Leptin administration restores normal LH pulses in fasted animals (Amstalden et al., 2000). Carvalho et al. (2013) reported higher expression of the leptin gene on adipose tissue in heifers fed high-energy diets; therefore, heifers with more adipose tissue can synthetize more leptin.

The onset of puberty is regulated by several hormones acting on the hypothalamus maturation (gonadostatic hypothesis) through feedback mechanisms involving the hypothalamic-pituitary-gonadal axis (Foster and Hileman, 2015). However, the nutritional modulation and the molecular mechanisms regulating the onset of puberty are not well understood (Foster and Hileman, 2015).

Prior to puberty, LH pulses are infrequent because of the estradiol and inhibin inhibition on GnRH secretion by the hypothalamus (Cardoso et al., 2015). The maturation of the hypothalamus that happens close to puberty results in changes in the intracellular architecture of follicular cells that, in turn, increases hormone synthesis. Thus, the elevation of serum estradiol concentration stimulates the secretion of GnRH (Perry, 2016). Gonadotropin-releasing hormone stimulates the anterior pituitary to release gonadotropins, follicle-stimulating hormone, and LH (Pernasetti et al., 2001), leading to a higher frequency in LH pulses and enabling ovulation (Foster and Hileman, 2015).

Several endocrine mechanisms have been studied to establish the relationship between nutrition and timing of puberty in heifers, among them the hormone leptin and the inhibitory action of NPY may be referred (Hausman et al., 2012). The leptin hormone inhibits the appetitestimulating effects of NPY and of agouti-related protein (AGRP) (Münzberg and Heymsfield, 2015). As observed in this study, the reduction of NPY1R expression by high energy intake suggests that it would make the hypothalamus less sensitive to NPY inhibition, enabling earlier onset of puberty. The role of NPY and its receptors in modulating puberty attainment of early- and late-maturing heifers was analyzed by Vaiciunas et al. (2008), who reported that NPY expression was not significantly altered in early-maturing heifers. However, the authors reported that early-maturing heifers had reduced expression of two hypothalamic NPY receptors, NPY1R and NPY4R. The results of the present study, together with the results of Vaiciunas et al. (2008), support the hypothesis that signaling through the NPY receptors modulates both nutrition and genetics effects on the attainment of puberty in Nellore heifers.

High-energy diet also reduced the hypothalamic expression of the ARRB1 gene in the present study. Betaarrestins are multifunctional proteins that contribute to desensitization of G-protein-coupled receptors (GPCRs) by blocking the receptor $\times$ G-protein interaction. Beta-arrestins are important not only in attenuating GPCR signaling in the continued presence of agonist, but also for receptor resensitization and down-regulation (Kilpatrick et al., 2012). These authors quantified neuropeptide $Y$ receptor association with $\beta$-arrestins and observed internalization of NPY1R to clathrin-coated pits after recruitment by $\beta$-arrestins when subjected to the agonist effect of NPY. Therefore, down-regulation of ARRB1 could be associated with lower sensibility of the hypothalamus to NPY action and, consequently, with hastening of puberty.

\section{Conclusions}

High energy intake promotes earlier attainment of puberty in Bos indicus heifers and increases body condition score at puberty. High energy intake reduces the hypothalamic expression of NPY1R and of $\beta$-arrestin1, suggesting a possible mechanism for nutritional modulation of puberty.

\section{Acknowledgments}

The authors would like to thank FAPESP (Process number 2008/01072-7) for the financial support.

\section{References}

Allen, C. C.; Alves, B. R. C.; Li, X.; Tedeschi, L. O.; Zhou, H.; Paschal, J. C.; Riggs, P. K.; Braga-Neto, U. M.; Keisler, D. H.; Williams, G. L. and Amstalden, M. 2012. Gene expression in the arcuate nucleus of heifers is affected by controlled intake of high- and low-concentrate diets. Journal of Animal Science 90:2222-2232. 
Amstalden, M.; Garcia, M. R.; Williams, S. W.; Stanko, R. L.; Nizielski, S. E.; Morrison, C. D.; Keisler, D. H. and Williams, G. L. 2000. Leptin gene expression, circulating leptin, and luteinizing hormone pulsatility are acutely responsive to short-term fasting in prepubertal heifers: relationships to circulating insulin and insulinlike growth factor I. Biology of Reproduction 63:127-133.

Amstalden, M.; Cardoso, R. C.; Alves, B. R. and Williams, G. L. 2014. Reproduction Symposium: Hypothalamic neuropeptides and the nutritional programming of puberty in heifers. Journal of Animal Science 92:3211-3222.

Atkins, J. A.; Pohler, K. G. and Smith, M. F. 2013. Physiology and endocrinology of puberty in heifers. Veterinary Clinics: Food Animal Practice 29:479-492.

Bohler, H.; Mokshagundam, S. and Winters, S. J. 2010. Adipose tissue and reproduction in women. Fertility and Sterility 94:795-825.

Cardoso, R. C.; Alves, B. R. C.; Sharpton, S. M.; Williams, G. L. and Amstalden, M. 2015. Nutritional Programming of Accelerated Puberty in Heifers: Involvement of Pro-Opiomelanocortin Neurones in the Arcuate Nucleus. Journal of Neuroendocrinology 27:647-657.

Carvalho, M. V.; Diniz-Magalhães, J.; Pereira, A. S. C.; Santos, M. V. and Silva, L. F. 2013. Effect of chronic infusion of leptin and nutrition on sexual maturation of zebu heifers. Journal of Animal Science 91:1207-1215.

Cônsolo, N. R. B.; Rodriguez, F. D.; Goulart, R. S.; Frasseto, M. O.; Ferrari, V. B. and Silva, L. F. P. 2015. Zilpaterol hydrochloride improves feed efficiency and changes body composition in nonimplanted Nellore heifers. Journal of Animal Science 93:4948-4955.

Day, M.; Imakawa, K.; Zalesky, D.; Kittok, R. J. and Kinder, J. E. 1986. Effects of restriction of dietary energy intake during the prepubertal period on secretion of luteinizing hormone and responsiveness of the pituitary to luteinizing hormone-releasing hormone in heifers. Journal of Animal Science 62:1641-1648.

Foster, D. L. and Hileman, S. M. 2015. Puberty in the sheep. p.1441-1486. In: Knobil and Neill's physiology of reproduction. 4th ed. Elsevier/Academic Press, Amsterdam.

Grandin, T. 2005. Special Report: Maintenance of good animal welfare standards in beef slaughter plants by use of auditing programs. Journal of the American Veterinary Medical Association 226:370-373.

Hausman, G. J.; Barb, C. R. and Lents, C. A. 2012. Leptin and reproductive function. Biochimie 94:2075-2081.

Hopper, H. W.; Williams, S. E.; Byerley, D. J.; Rollosson, M. M.; Ahmed, P. O. and Kiser, T. E. 1993. Effect of prepubertal body weight gain and breed on carcass composition at puberty in beef heifers. Journal of Animal Science 71:1104-1111.

Kilpatrick, L.; Briddon, S. and Holliday, N. 2012. Fluorescence correlation spectroscopy, combined with bimolecular fluorescence complementation, reveals the effects of $\beta$-arrestin complexes and endocytic. Biochimica et Biophysica Acta 1823:1068-1081.

Klein, B. K. 2012. Cunningham's textbook of veterinary physiology. 5th ed. Veterinary records. Blacksburg, VA, USA.

Lanna, D. P. D.; Boin, C.; Alleoni, G. F. and Leme, P. R. 1995. Estimativa da composição química corporal de tourinhos nelore através da gravidade específica. Revista da Sociedade Brasileira de Zootecnia 24:351-362.

Lanna, D. P. D.; Morais, J. P.; Boin, C.; Fox, D. G.; Leme, P. R. and Castro, F. B. D. 1999. Performance and body composition of heifers fed two concentrate levels and sugarcane bagasse submitted to different hydrolysis processes. Revista Brasileira de Zootecnia 28:412-420.

Lohakare, J. D.; Südekum, K. H. and Pattanaik, A. K. 2012. Nutritioninduced changes of growth from birth to first calving and its impact on mammary development and first-lactation milk yield in dairy heifers: A review. Asian-Australasian Journal of Animal Sciences $25: 1338-1350$

Münzberg, H. and Heymsfield, S. B. 2015. Leptin, obesity, and leptin resistance. p.67-78. In: Leptin: Regulation and clinical applications. Dagogo-Jack, ed. Springer International Publishing, Cham, Switzerland.

Nepomuceno, D. D.; Pires, A. V.; Ferraz, M. V.; Biehl, M. V.; Gonçalves, J. R.; Moreira, E. M. and Day, M. L. 2017. Effect of pre-partum dam supplementation, creep-feeding and post-weaning feedlot on age at puberty in Nellore heifers. Livestock Science 195:58-62.

NRC - National Research Council. 2000. Nutrient requirements of beef cattle. 7 th ed. National Academy Press, Washington, DC.

NRC - National Research Council. 2001. Nutrient requirements of dairy cattle. 7th rev. ed. National Academy Press, Washinton, DC.

Patterson, D. J.; Corah, L. R. and Brethour, J. R. 1990. Response of prepubertal and $\times$ heifers to melengestrol acetate with or without gonadotropin-releasing hormone. Theriogenology 33:661-668.

Pernasetti, F.; Vasilyev, V. V.; Rosenberg, S. B.; Bailey, J. S.; Huang, H. J.; Miller, W. L. and Mellon, P. L. 2001. Cell-specific transcriptional regulation of follicle-stimulating hormone- $\beta$ by activin and gonadotropin-releasing hormone in the L $\beta \mathrm{T} 2$ pituitary gonadotrope cell model. Endocrinology 142:2284-2295.

Perry, G. A. 2016. Factors affecting puberty in replacement beef heifers. Theriogenology 86:373-378.

Putrino, S. M.; Leme, P. R.; Luz e Silva, S.; Alleoni, G. F.; Lanna, D. P. D.; Lima, C. G. and Grossklaus, C. 2006. Net energy and protein requirements for weight gain of Brangus and Nellore bulls fed diets containing different concentrate proportions. Revista Brasileira de Zootecnia 35:292-300.

Rawlings, N. C.; Evans, A. C.; Honaramooz, A. and Bartlewski, P. M. 2003. Antral follicle growth and endocrine changes in prepubertal cattle, sheep and goats. Animal Reproduction Science 78:259-270.

Roland, A. V. and Moenter, S. M. 2011. Regulation of gonadotropinreleasing hormone neurons by glucose. Trends in Endocrinology and Metabolism 22:443-449.

Samadi, F.; Blache, D.; Martin, G. B. and D’Occhio, M. J. 2014. Nutrition, metabolic profiles and puberty in Brahman (Bos indicus) beef heifers. Animal Reproduction Science 146:134-142.

Vaiciunas, A.; Coutinho, L.; Meirelles, F. V.; Pires, A. V. and Silva, L. F. P. 2008. Leptin and hypothalamic gene expression in early-and late-maturing Bos indicus Nellore heifers. Genetics and Molecular Biology 31:657-664.

Vaughn, S. E. 2012. Review of the third edition of the Guide for the care and use of agricultural animals in research and teaching. Journal of the American Association for Laboratory Animal Science 51:298-300.

Velazquez, M. A.; Spicer, L. J. and Wathes, D. C. 2008. The role of endocrine insulin-like growth factor-I (IGF-I) in female bovine reproduction. Domestic Animal Endocrinology 35:325-342.

Yelich, J. V.; Wettemann, R. P.; Dolezal, H. G.; Lusby, K. S.; Bishop, D. K. and Spicer, L. J. 1995. Effects of growth rate on carcass composition and lipid partitioning at puberty and growth hormone, insulin-like growth factor I, insulin, and metabolites before puberty in beef heifers. Journal of Animal Science 73:2390-2405.

Yuan, J. S.; Reed, A.; Chen, F. and Stewart, C. N. 2006. Statistical analysis of real-time PCR data. BMC Bioinformatics 7:85-97.

Zieba, D. A.; Szczesna, M.; Klocek-Gorka, B.; Molik, E.; Misztal, T.; Williams, G. L.; Romanowicz, K.; Stepien, E.; Keisler, D. H. and Murawski, M. 2008. Seasonal effects of central leptin infusion on secretion of melatonin and prolactin and on SOCS-3 gene expression in ewes. Journal of Endocrinology 198:147-155. 